\title{
Academic Freedom and Librarians' Research and Scholarship in Canadian Universities
}

\author{
Mary Kandiuk and Harriet M. Sonne de Torrens
}

\begin{abstract}
This study examines the extent to which librarians employed at Canadian universities have academic freedom protection with respect to the right and responsibility to engage in research and scholarship as part of their normal workload and the right to pursue unrestricted lines of inquiry in research and scholarship. An analysis of the terms and conditions of employment for Canadian academic librarians and the results of a nationwide survey reveal that the majority are protected by academic freedom in their contractual agreements. The findings also reveal that the inclusion of research and scholarship as part of normal workload is a challenge for many librarians, definitions for research and scholarship vary across institutions, and time constraints impede the ability of librarians to conduct research and scholarship.
\end{abstract}

\begin{abstract}
Introduction
Librarians fill a unique occupational domain in the university. Historically, they are aligned with the teaching faculty in terms of fulfilling the academic mission of the university. Unlike faculty, however, librarians' roles have evolved within hierarchical managerial structures that do not grant many of the academic rights and professional autonomy that teaching faculty have attained. Academic libraries, as Rachel FlemingMay and Kimberly Douglass note, "more closely resemble Mintzberg's description of the 'machine bureaucracy' in which roles are designated by work assignment, middle management is more robust, and decision making and communication tend to be hierarchical."1 Professional autonomy underpins faculty culture, relying on such rights and mechanisms as academic freedom, peer review, tenure, and collegial governance structures and processes. ${ }^{2}$ Meanwhile, librarians have historically found themselves excluded from the larger institutional culture and "confined to the library," which is perceived by the broader community as their sole domain and contributes to their "academic isolation." ${ }^{3}$ However, as pointed out by Fleming-May and Douglass, the roles of librarians within the university have evolved considerably with respect to status, qualifications, and responsibilities. ${ }^{4}$ Approximately 44 percent of librarians
\end{abstract}

Mary Kandiuk is Visual Arts, Design E Theatre Librarian / Senior Librarian at York University; email: mkandiuk@yorku.ca. Harriet M. Sonne de Torrens is Librarian at University of Toronto Mississauga; email: harriet.sonne@utoronto.ca. (C2018 Mary Kandiuk and Harriet M. Sonne de Torrens, AttributionNonCommercial (http://creativecommons.org/licenses/by-nc/4.0/) CC BY-NC. 
in the United States who work at ARL institutions have faculty status and tenure. ${ }^{5}$ In Canada, librarians who are members of academic staff associations, the majority of which are certified unions, generally hold academic status that includes tenure (sometimes entitled continuing appointment or permanent status). ${ }^{6}$ The right of librarians to engage in research and scholarship within academic libraries has been acknowledged by library associations both within and outside Canada ${ }^{7}$ and national organizations such as the Canadian Association of University Teachers (CAUT) and American Association of University Professors (AAUP). ${ }^{8}$ Research and scholarship are typically required of academic librarians employed in ARL member libraries seeking tenure or continuing appointment. ${ }^{9}$ Four out of five $(81 \%)$ of Canadian academic librarians who are members of university associations have "scholarly activities" included in their "actual workload or potential workload."10 In this context, there is an ever pressing need to accord them the same rights and freedoms as their faculty counterparts.

This line of inquiry examines to what extent academic librarians employed at Canadian universities have academic freedom with respect to the right to conduct research and scholarship and to pursue unrestricted lines of inquiry in their scholarship. Specifically, it seeks to answer:

- Are librarians protected by an academic freedom statement that includes research and scholarship in their terms of employment?

- Are research and scholarship included as part of the professional practice and/ or normal workload for librarians?

- How are research and scholarship for academic librarians defined?

- Are there restrictions imposed on librarians' research and scholarship? If so, what kinds of restrictions?

This study is based on an analysis of current collective agreements and employment policies for academic librarians employed at Canadian universities and a nationwide survey distributed to librarians employed at Canadian universities in 2014.

\section{Literature Review}

There is a substantial body of literature that examines the role of research in the profession of academic librarianship. However, the focus has been largely on attitudes toward research, ${ }^{11}$ barriers to conducting research, ${ }^{12}$ the value of conducting research, ${ }^{13}$ and fostering research. ${ }^{14}$ Much has also been written about evidence-based practice research whereby librarians seek to improve library services by incorporating the results of qualitative and quantitative research into their daily practice. ${ }^{15}$ Less examined in the literature is the pursuit of scholarship by librarians in disciplines beyond Library and Information Studies (LIS), including creative disciplines, and the acceptance and support of librarians engaged in research and scholarship by academic libraries. This is notable, as the value of subject or disciplinary expertise in the profession is recognized by numerous authors in the literature and is one of the proficiency skills noted in the ACRL Standards for Proficiencies for Instruction Librarians and Coordinators: A Practical Guide (2008). ${ }^{16}$ Many academic librarians serve as subject specialists or liaisons for departments or faculties and are often assigned specific subject responsibilities on the basis of an advanced degree or subject background in the area. ${ }^{17}$ As pointed out by Susan Thomas and Anne Leonard, "librarianship is a professional degree with the terminal MLS degree, not a scholarly field" and librarians have spent a greater portion of their postsecondary education pursuing additional degrees in a scholarly discipline. ${ }^{18}$ Numerous studies point to the rise of advanced degrees, both a second master's and the PhD, among librarians. ${ }^{19}$

Within the profession, there exists a tension between scholarly activity and practice, with a perceived discouragement noted of the former. ${ }^{20}$ Studies have revealed that 
the emphasis in LIS programs is not on producing scholars but instead to ensure that librarians, as professionals and practitioners, can perform in a wide range of academic settings, adding to the tensions. ${ }^{21}$

What is less discussed within the profession, or which may not be fully appreciated, is the concept of academic freedom, as opposed to intellectual freedom, and how this impacts librarians in their scholarly pursuits. As described by Jesse Mann, intellectual freedom and academic freedom are "related but distinct concepts," and the academic library is a "critical point of their intersection." 22 Academic freedom can be viewed as an "application of intellectual freedom in the university setting," according to Richard Danner and Barbara Bintliff. ${ }^{23}$ However, when intellectual freedom is described for librarians, it often refers to the exercise of their responsibilities in the administration of libraries. ${ }^{24}$ The focus, as stated by Shannon Oltmann, is on "access to different ideas," whereas in academic freedom it is "on expression." ${ }^{25}$ When the phrase "intellectual freedom" is used for faculty, it is interpreted in the broadest sense; that is, to include academic freedom protection. ${ }^{26}$ In his 2007 study of the scholarship of Canadian academic librarians, David Fox reported that "more than half (51.4\%) of survey respondents indicated that scholarship is either required or encouraged at their university" and that librarians pursue "a rich array of scholarly interests that extend well beyond the everyday issues of professional practice." ${ }^{27} \mathrm{He}$ found that "scholarship is naturally expected during sabbatical and study leave, where available" and for "35 percent of participants, scholarship was also expected as an integral part of their professional responsibilities on an ongoing basis." ${ }^{28}$ Marni Harrington and Natasha Gerolami's 2014 analysis of 24 Canadian collective agreements found significant variations in language and rights for librarians pursuing research/scholarly activity. ${ }^{29}$ They found that additional requirements relating to intellectual freedom and the dissemination of information were imposed on librarians that were not imposed on faculty. ${ }^{30}$ However, their study does not explore in depth the issue of academic freedom as relates to the research and scholarly activity of librarians. This study expands on the scholarship of Fox and Harrington and Gerolami.

\section{Background}

Academic freedom, as an essential principle and protective right, has remained a core value in the history and mandate of Canadian universities. ${ }^{31}$ The shift in librarianship from a male-dominated profession in the nineteenth century to a declared feminine profession in the first half of the twentieth century, ${ }^{32}$ and the development of information science as a discipline and profession, gradually led to occupational gaps between teaching faculty and librarians that proved difficult to bridge, ${ }^{33}$ creating a greater disparity between the two groups. In more recent times, from the 1960s to the 1980s, the profession of academic librarianship underwent substantial changes that included the reinforcement of academic freedom for librarians, a quest for faculty status and the right to professional autonomy. Efforts in Canada paralleled similar efforts in the United States $^{34}$ and emerged simultaneously with the rise of feminism, ${ }^{35}$ the establishment of new Canadian universities from the late 1950s through the 1980s, the unionization of faculty associations, and the emergence of paraprofessional library workers. ${ }^{36}$ During this period, Canadian librarians turned to their U.S. colleagues and U.S. library associations for supportive policies and statements. ${ }^{37}$ The added developments of provincial funding for graduate programs, the rise in student enrollment, and the growth of specialized fields of study and knowledge all contributed to the higher expectations placed on academic librarians to fulfill the role previously held by teaching faculty in the building of resources and collections. Faculty assuming responsibility for the development of library collections was no longer a viable option. ${ }^{38}$ In Ontario, for example, 
in 1964 the presidents of the provincially funded universities reviewed the need for more academic librarians due to the expansion of graduate programs and suggested major revisions to the education of academic librarians to meet the specialized needs of graduate studies. ${ }^{39}$ The previous professional requirement of an undergraduate degree in library science was replaced with a master's professional degree, resulting in longer periods of study preceded by the acquisition of an undergraduate degree in another discipline. ${ }^{40}$ Many librarians also sought additional graduate degrees in academic fields to better support their communities and growing specialized collections. ${ }^{41}$

Defining academic freedom for the profession of academic librarianship and the broader academic community begins with an acknowledgement of the basic freedoms to which all Canadian citizens are entitled as outlined in the Canadian Charter of Rights and Freedoms ${ }^{42}$ and the United Nations' Universal Declaration of Human Rights ${ }^{43}$ to which Canada is a signatory. ${ }^{44}$ Academic freedom is a requirement for librarians to fulfil their professional responsibilities, including the pursuit of research and scholarship. While academic freedom statements may vary from one institution to the next, they protect the right and freedom to pursue uncensored and unrestricted research and scholarship and to publish and disseminate the results unimpeded and unencumbered. These rights have long been advocated by leading academic associations in North America. ${ }^{45}$ The Guidelines for the Appointment, Promotion and Tenure of Academic Librarians (June 2010) and Faculty Status for College and University Librarians (October 2012) issued by the Association of College \& Research Libraries (ACRL) specify that academic librarians require academic freedom and that promotion and tenure "criteria and standards may differ from traditional classroom faculty, but they must be comparable in rigor and content." 46 In the United States, academic freedom is among the rights protected by the First Amendment. ${ }^{47}$ In Canada, where faculty and librarians do not have the same constitutional protections as their American counterparts, they have sought academic freedom rights and protection through negotiated contractual agreements outlining terms and conditions of employment. ${ }^{48}$

\section{Method}

The following section outlines the two types of information examined for this study. First, the written terms of employment for Canadian academic librarians in negotiated collective agreements and policies; second, the empirical research collected via a survey completed by Canadian academic librarians.

\section{Collective Agreements and Policies}

The collective agreements and policies governing the working conditions and terms of employment for academic librarians at 53 Canadian universities were analyzed (see appendix A). Unlike the United States, in Canada the majority of postsecondary institutions are public as opposed to private. Approximately 90 percent of faculty associations at Canadian universities are unionized and have negotiated collective agreements or similar types of agreements outlining the terms and conditions of employment for faculty and librarians. In the majority of cases, librarians are covered under the same collective agreement as faculty although often under separate clauses. ${ }^{49}$ The selected institutions are members of Universities Canada and CAUT and represent the major undergraduate, comprehensive, and medical-doctoral institutions in Canada. The 53 institutions represent 55 percent of the total 96 public Canadian universities listed in Universities Canada for ten Canadian provinces. ${ }^{50}$ The intent was to provide a broad but cohesive sample of agreements and policies from across Canada. Included are historically established institutions as well as relatively new universities, some of which originated as colleges or vocational institutions. All are research and teaching degree-granting institutions employing a sufficient number of academic librarians to 
allow for a meaningful analysis. Faculty and librarians at 46 of the 53 institutions are unionized. Of those that are unionized, 44 out of 46 unionized institutions include librarians in the same bargaining unit as faculty. In the case of the 7 out of 53 institutions that are not unionized, 3 institutions include librarians in the same association as faculty.

Collective agreements and policies were obtained from institutional websites and the Canadian federal government Negotech database. ${ }^{51}$ Each collective agreement and policy was searched using analogous keywords for academic freedom (freedom of expression, intellectual freedom), workload (working conditions, duties, rights and responsibilities) and scholarship (research, creative activities/work, professional development, education, and so on), and specific topics such as the right to pursue scholarship in other disciplines (subject expertise, academic expertise, areas of specialization, and the like). In addition, all related clauses and supplemental documents pertaining to librarians' appointment, promotion, and areas of responsibilities were examined to determine if support, specific approaches, or restraints are codified.

\section{Survey}

A web-based survey entitled "Canadian Academic Librarians Academic Freedom Survey" was developed using Survey Monkey that included both closed and openended questions. This was an anonymous and voluntary survey approved by the Ethics Review Committees at the University of Toronto and York University. The survey was distributed via multiple national, provincial, and specialized librarians' lists from March 21 to April 11, 2014. The first part, ${ }^{52}$ a small subset of which is examined in this study, was composed of twenty-nine questions that relate to academic freedom protection with respect to: the performance of academic activities; experiences in the exercise of academic freedom during the performance of academic activities; attitudes toward and understanding of academic freedom; and the external and internal factors that have an impact on academic freedom. There were 348 responses from librarians. Nearly nine out of ten $(88 \%, \mathrm{n}=284)$ of respondents identified as being employed at a university; 13 percent identified as being employed at a college. As there is no standard requirement for research for librarians employed by colleges, only the responses from librarians employed at universities were used for this analysis. The responses were divided into three groups: librarians that belong to a certified association that includes faculty; librarians that belong to a certified association that includes only librarians; and librarians that belong to a noncertified association that included faculty and librarians. Librarians that fell outside these three groups formed a sample too small to be included.

\section{Findings}

\section{Collective Agreements and Policies Analysis}

The majority of Canadian universities surveyed employ the same academic freedom language and protection for both faculty and librarians in their negotiated agreements. More than seven out of ten $(72 \%, n=38)$ of the collective agreements and policies include an academic freedom statement that protects both faculty and librarians' research and scholarship (see table 1$)$. A remaining 19 percent $(n=10)$ of the policies do not have an academic freedom statement that protects librarians' research and scholarship, and 10 percent $(n=5)$ of the policies have academic freedom statements that pose restrictions on librarians' research and scholarship. At McMaster University, where librarians have unionized separately from faculty, Article $8.02 \mathrm{~b}$ states that "the diversity of traditions across disciplines necessitates that an employee's freedom to pursue his/her own direction of research will vary according to individual supervisor/employee arrangements" (CA: 8.02b; collective agreements abbreviated to CA followed by number of article). In other cases, where librarians do not have full academic freedom protection, 
academic freedom may be restricted to librarians' duties and/or responsibilities from which research and scholarship are excluded. For example, the academic freedom statement at Simon Fraser University pertains to librarians' "right to express their academic judgment in the development of the Library collection and to make the collection accessible to all users in accordance with the University Library policies" (CA: 12.6). Librarians' research and scholarship are not included in their academic freedom protection. Article 36.12 states: "Currency in their specific field of activity is essential, but there is no requirement for research activity" (CA: 36.12).

\begin{tabular}{|l|c|c|}
\hline \multicolumn{3}{|c|}{ TABLE 1 } \\
Academic Freedom Statements for Librarians' Research and Scholarship \\
\hline Included (Yes) / Not Included (No) & No. of Institutions & \% of Institutions \\
\hline Yes & 38 & $72 \%$ \\
\hline No & 10 & $19 \%$ \\
\hline Other (with conditions, ambiguous) & 5 & $10 \%$ \\
\hline
\end{tabular}

\section{Research and Scholarship in Professional Practice and/or Normal Workload}

More than half $(52 \%, \mathrm{n}=27)$ of the 53 collective agreements/policies examined stipulate that research and scholarship are required (see table 2). Just under two out of ten (17\%, $\mathrm{n}=9)$ offer research and scholarship as an option. Combined, 69 percent $(\mathrm{n}=36)$ of the 53 policies note research and scholarship as a component of librarians' workload. In those cases where research and scholarship are an option, permission is required and the processes for pursuing research and scholarship vary. At the University of Alberta, for example, "a staff member may participate in professional and scholarly research and may request that individual research projects be included in the specific responsibilities assigned" (CA: 7.3). At the University of Ottawa, a librarian member is not "required or obliged" to engage in scholarly activities not specifically "mentioned in her job description" (CA: 21.2.2). Every member, however, shall have the "right to devote a reasonable proportion of her scheduled working hours" to "scholarly activities or academic service activities... provided the University Librarian is informed of the extent and general nature of such activities, and she does not find that they are likely to be detrimental to the member's performance of the duties specified in her job description" (CA: 21.2.2.b).

\begin{tabular}{|l|c|c|}
\hline \multicolumn{3}{|c|}{$\begin{array}{c}\text { TABLE } 2 \\
\text { Research and Scholarship Included in Professional Practice and/or Normal } \\
\text { Workload }\end{array}$} \\
\hline Included/Not Included & No. of Institutions & $\%$ of Institutions \\
\hline Required & 27 & $52 \%$ \\
\hline Optional & 9 & $17 \%$ \\
\hline Not Included & 17 & $32 \%$ \\
\hline
\end{tabular}

\section{Definitions of Librarians' Research and Scholarship}

In the 52 percent $(n=27)$ of the policies that require research and scholarship in the normal workload of librarians, the definitions for research and scholarship vary (see table 3). For a detailed list, see appendix B. Where there are analogous definitions of scholarship for both faculty and librarians, such as at Laurentian University, they usu- 
ally include "creative activities," acknowledging the contributions of musical, literary, and artistic production by both faculty and librarians (CA: 6.10). Meanwhile, "academic activity" may be used when inclusivity is sought to reflect the contributions of all members in a collective agreement. Huntington University uses "academic activity" in the broadest sense for teachers and librarians to include scholarly competence in areas of expertise, teaching, professional development, research, and creative projects (CA: 11.02-11.03). However, "academic activity" can also denote the opposite. For librarians at Western University, academic activity must be “...relevant to librarianship or archival practice" (CA: 3.0). In other instances, scholarship for librarians includes educational pursuits such as the attainment of advanced degrees in librarianship or pertinent degrees, which enables librarians to pursue these goals in a study or research leave as at the University of British Columbia (CA: 4.30-4.04). In total, 33 percent ( $\mathrm{n}=$ 9) of institutions that require research and scholarship in librarians' workload affirm that all academic disciplines/subjects may be considered in the librarians' research and scholarship, whereas 66 percent $(n=18)$ apply conditions or are ambiguous. In comparison, 70 percent $(n=19)$ include professional development as a component of research and scholarship. At Lakehead University, if scholarship is pursued, it must be "to increase knowledge and understanding and to improve the professional competence of librarians" (CA: 16.11.02).

In 19 percent $(n=5)$ of the collective agreements/policies, research and scholarship are restricted to professional practice and LIS; another 11 percent $(n=3)$ are ambiguous. At Concordia University, research and scholarship for librarians is defined as "the development of professional knowledge through research, scholarly and critical or creative work within the field of librarianship" (CA: 17.01.b.). The University of New Brunswick's collective agreement stipulates that the scholarship conducted by librarians and archivists shall "... in the course of their duties in accordance with the provisions of section 16.C.02, it shall have as its primary objective to increase knowledge and understanding, to improve the professional competence of Librarians and Archivists, and to enhance library services" (CA: 16.C.03). The University of Prince Edward Island Faculty Association collective agreement defines scholarship for librarians as "Scholarly and/or Professional Development Activity," which includes "scholarly contributions to the discipline of librarianship or other relevant disciplines" (CA: A9.4.). The phrase "relevant discipline" is not defined. At the University of Toronto, conflicting statements in the research and study leaves 1978 policy notes that the proposed research should be "...made use of in the librarian's continuing employment with the University," suggesting that the research and scholarship need to be related to or used in the professional work of the librarian (PFL: 51).

\begin{tabular}{|c|c|c|c|c|c|c|}
\hline \multicolumn{7}{|c|}{$\begin{array}{c}\text { TABLE } 3 \\
\text { Summary of Definitions of Librarians' Research and Scholarship }\end{array}$} \\
\hline & \multicolumn{2}{|c|}{ Yes } & \multicolumn{2}{|c|}{ No } & \multicolumn{2}{|c|}{$\begin{array}{c}\text { Other/ } \\
\text { Ambiguous }\end{array}$} \\
\hline Scholarship required in workload & $100 \%$ & $\mathrm{n}=27$ & 0 & 0 & 0 & 0 \\
\hline $\begin{array}{l}\text { Scholarship includes all academic } \\
\text { disciplines }\end{array}$ & $33 \%$ & $\mathrm{n}=9$ & $56 \%$ & $\mathrm{n}=15$ & $11 \%$ & $\mathrm{n}=3$ \\
\hline $\begin{array}{l}\text { Scholarship includes professional } \\
\text { development }\end{array}$ & $70 \%$ & $\mathrm{n}=19$ & $30 \%$ & $\mathrm{n}=8$ & 0 & 0 \\
\hline $\begin{array}{l}\text { Scholarship restricted to professional } \\
\text { practice and/or LIS }\end{array}$ & $15 \%$ & $\mathrm{n}=4$ & $67 \%$ & $\mathrm{n}=18$ & $19 \%$ & $\mathrm{n}=5$ \\
\hline
\end{tabular}




\section{Restrictions on Research and Scholarship}

One restriction that impedes the ability of librarians to pursue research and scholarship is dedicated time within the regular daily workload. In the 27 collective agreements/ policies that require librarians to engage in research and scholarship, less than half allocate dedicated time within the work week for this activity. Nearly two out of ten $(19 \%, n=5)$ distribute workload according to percentages for librarians. At Laurentian University, 40 percent of workload is allocated for research and scholarship compared to 30 percent at the University of Guelph, 25 percent at Western University, and 10 to 15 percent at the University of Toronto. In addition, a specified number of days per year is granted to librarians at some institutions to pursue research and/or professional development. Nearly one-third $(30 \%, \mathrm{n}=8)$ of the collective agreements/policies indicate librarians have research and/or professional development days, which can range from five days (University of Prince Edward Island) up to 24 days (Queen's University). The remaining 41 percent $(n=11)$ do not specifically allocate time for research and scholarship. A number employ language parity for all members (such as Brandon, Huntington, and Laurentian universities). However, this does not address the unique professional demands on librarians' time in the library.

Other institutions, such as Algoma University, describe the balance of professional practice demands and scholarship by referring to workload as "... appropriate combinations of..." (CA: 2.07). At institutions where librarians' research and scholarship are an option, such as Carleton University, the collective agreement states librarians have the right (CA: 13.3.b.iii) "...to devote time during working hours to research projects and/or professional development activities in accordance with Article 15.4(c)." Article 15.4(c) states librarians have the right to research projects "...subject to operational requirements" (CA: 15.4(c)). In other collective agreements/policies, successful requests to reduce workloads to facilitate research and scholarship are contingent on a proven research record. For example, at Concordia University, the policy states, "Clear evidence of scholarship/research can result in reduced duties" (CA: 17.04.f).

Other impediments impacting librarians' research and scholarship appear in the policies where librarians are not required to engage in scholarship or when research and scholarship are an option. At the University of Alberta, the librarians are eligible for "Professional Leave" (CA: 9). The application for leave asks that the librarian provide a statement outlining the benefit of the leave to the applicant and to the library and the level of salary requested. Article 9.05.4 states, "When the leave is determined to be of primary benefit to the Library, the salary level shall be one-hundred percent of full salary" (CA: 9.05.4). However, should the research being undertaken be deemed not to be of primary value to the Library and only to the individual then "... the salary level shall be fifty percent of full salary" (CA: 9.05.2). At Carleton University, where scholarship is an option, the workload of librarians corresponds to individual job descriptions. Librarians may pursue scholarship subject to "operational requirements" (CA: 15.4.c.).

\section{Survey Results}

The 2014 national survey of academic librarians proved useful in revealing librarians' perceptions regarding what freedom they have or are able to exercise when pursuing research and scholarship.

\section{Research and Scholarship in Professional Practice and/or Normal Workload}

The survey revealed that the percentage of librarians employed at Canadian universities whose professional responsibilities require research and scholarship has increased since Fox's 2007 study, ${ }^{53}$ with the majority responding yes. Those belonging to a certified faculty association that includes faculty reported the highest number $(71 \%$; $n=115)$, 
followed by those who belong to a noncertified association that includes faculty and librarians $(63 \% ; n=27)$. Those who are members of a certified association that includes only librarians reported the lowest $(56 \% ; n=6)$. A small number of total respondents $(n=6)$ indicated that, while research was not required, it was encouraged or expected.

A high percentage of librarians from all groups indicated that they were able to conduct research as part of their normal responsibilities without prior approval (see table 4). Those librarians who belonged to a certified association reported the greatest ability.

\begin{tabular}{|c|c|c|c|c|c|c|}
\hline \multicolumn{7}{|c|}{$\begin{array}{c}\text { TABLE } 4 \\
\text { Approval for Research as Part of Normal Responsibilities }\end{array}$} \\
\hline \multicolumn{7}{|c|}{$\begin{array}{l}\text { Do librarians at your institution require prior approval (written or verbal) for research } \\
\text { activity as part of normal responsibilities? }\end{array}$} \\
\hline & \multicolumn{2}{|c|}{ Yes } & \multicolumn{2}{|c|}{ No } & \multicolumn{2}{|c|}{ Sometimes } \\
\hline Certified Faculty + Librarians & $12 \%$ & $\mathrm{n}=20$ & $67 \%$ & $\mathrm{n}=109$ & $16 \%$ & $\mathrm{n}=26$ \\
\hline Certified Librarians & $13 \%$ & $\mathrm{n}=1$ & $75 \%$ & $\mathrm{n}=6$ & $13 \%$ & $\mathrm{n}=1$ \\
\hline Noncertified Faculty + Librarians & $25 \%$ & $\mathrm{n}=11$ & $48 \%$ & $\mathrm{n}=21$ & $16 \%$ & $\mathrm{n}=7$ \\
\hline
\end{tabular}

When asked who provided approval, the most frequently cited positions providing approval were middle managers and administration (such as Department Head, Supervisor, Associate Librarian, or Deputy Chief Librarian).

\section{Restrictions on Research}

Table 5 reveals the role administrators play in the research agenda of librarians. More than 60 percent of respondents indicated that prior approval was "sometimes" required for research agendas, whether a member of a unionized or nonunionized association. The large number of respondents in table 6 who responded "sometimes" may reflect the difference between research conducted as part of normal responsibilities as opposed to research conducted as part of sabbatical or extended research leave where formal approval is normally required, which the survey did not probe.

\begin{tabular}{|c|c|c|c|c|c|c|}
\hline \multicolumn{7}{|c|}{$\begin{array}{c}\text { TABLE } 5 \\
\text { Approval for Research Agenda }\end{array}$} \\
\hline \multicolumn{7}{|c|}{$\begin{array}{l}\text { Do librarians at your institution require prior approval (written or verbal) for research } \\
\text { agenda (such as subject matter, discipline, topics)? }\end{array}$} \\
\hline & \multicolumn{2}{|c|}{ Yes } & \multicolumn{2}{|c|}{ No } & \multicolumn{2}{|c|}{ Sometimes } \\
\hline Certified Faculty + Librarians & $12 \%$ & $\mathrm{n}=20$ & $17 \%$ & $\mathrm{n}=27$ & $61 \%$ & $\mathrm{n}=99$ \\
\hline Certified Librarians & $13 \%$ & $\mathrm{n}=1$ & $25 \%$ & $\mathrm{n}=2$ & $63 \%$ & $\mathrm{n}=5$ \\
\hline Noncertified Faculty + Librarians & $16 \%$ & $\mathrm{n}=7$ & $9 \%$ & $\mathrm{n}=4$ & $63 \%$ & $\mathrm{n}=27$ \\
\hline
\end{tabular}

Tables 6 and 7 reveal that librarians who are members of a certified faculty association that includes both faculty and librarians have the greatest freedom to conduct research on a topic of their own choosing. Those librarians who belong to a certified association that includes only librarians reported the least amount of freedom.

In the survey results, several respondents indicated that research must be related to librarianship or one's professional position, regardless of whether this was stipulated in a collective agreement or policy. This raises questions regarding the influence of library administrators and their support of subject expertise, outside of LIS, with respect to 


\begin{tabular}{|c|c|c|c|c|c|c|}
\hline \multicolumn{7}{|c|}{$\begin{array}{c}\text { TABLE } 6 \\
\text { Right to Freely Pursue Research }\end{array}$} \\
\hline \multicolumn{7}{|c|}{$\begin{array}{l}\text { I am able to conduct research, disseminate, and publish on subjects/topics and in the } \\
\text { discipline of my own choosing. }\end{array}$} \\
\hline & \multicolumn{2}{|c|}{ Yes } & \multicolumn{2}{|r|}{ No } & \multicolumn{2}{|c|}{ Sometimes } \\
\hline Certified Faculty + Librarians & $75 \%$ & $\mathrm{n}=114$ & $3 \%$ & $\mathrm{n}=5$ & $16 \%$ & $\mathrm{n}=25$ \\
\hline Certified Librarians & $33 \%$ & $\mathrm{n}=2$ & $33 \%$ & $\mathrm{n}=2$ & $33 \%$ & $\mathrm{n}=2$ \\
\hline Noncertified Faculty + Librarians & $69 \%$ & $\mathrm{n}=29$ & $2 \%$ & $\mathrm{n}=1$ & $17 \%$ & $\mathrm{n}=7$ \\
\hline \multicolumn{7}{|c|}{$\begin{array}{c}\text { TABLE } 7 \\
\text { Restrictions and Guidelines for Research }\end{array}$} \\
\hline \multicolumn{7}{|c|}{$\begin{array}{l}\text { Are there any restrictions or guidelines at your institution regarding what librarians may } \\
\text { or may not do in the following areas of academic activity? }\end{array}$} \\
\hline \multicolumn{3}{|c|}{ Research (such as subject matter, discipline, topics) } & & & & \\
\hline & \multicolumn{2}{|c|}{ Yes } & \multicolumn{2}{|c|}{ No } & \multicolumn{2}{|c|}{ Sometimes } \\
\hline Certified Faculty + Librarians & $11 \%$ & $\mathrm{n}=77$ & $72 \%$ & $\mathrm{n}=111$ & $16 \%$ & $\mathrm{n}=24$ \\
\hline Certified Librarians & $43 \%$ & $\mathrm{n}=3$ & $57 \%$ & $\mathrm{n}=4$ & 0 & 0 \\
\hline Noncertified Faculty + Librarians & $27 \%$ & $\mathrm{n}=11$ & $61 \%$ & $\mathrm{n}=25$ & $10 \%$ & $\mathrm{n}=4$ \\
\hline
\end{tabular}

librarians' scholarship. In fact, some respondents indicated that subject discipline-related research was not acceptable. A recurring theme throughout the written responses was that research must benefit the institution, in this case the library.

Respondents provided many comments relating to this part of the survey, which revealed the pressure on librarians to conduct research that is acceptable to library administration. The responses also revealed a great degree of discretion on the part of library administrators with respect to the approval of research agendas. Some examples:

- "Theoretically, yes. But the culture of research in librarianship means that certain things aren't seen as valuable or applicable, and this makes its way into the evaluation done by admin. This, in turn, indirectly shapes the research agendas that new librarians tend to undertake."

- "There is an assumption that the research I conduct should be aligned with my professional practice and day-to-day work. It would be very difficult to find the time to carry out research on topics that are tangential to my responsibilities, and I do not believe such research would be supported."

- "Within the confines of my job description if I want to have it as part of my job duties or be evaluated. If not, then I can research anything I want, but not necessarily on work time."

- "Yes if in any field in library-science (as per our contract); no to research in any other discipline."

- "I have had to deal with interference from Library Management. Library management strongly encouraged me to do research in LIS."

\section{Discussion}

The majority of Canadian universities recognize the importance of employing the same academic freedom language and protection for both faculty and librarians as endorsed in ACRL's Standards for Faculty Status for Academic Librarians. ${ }^{54}$ Only a few institutions have deviated from this practice. The lack of academic freedom protection for the research and scholarship of librarians suggests a failure to recognize the evolv- 
ing roles and responsibilities of academic librarians. For the most part, however, the academic freedom statements by the majority of Canadian universities examined in this study do not appear to be the tension points concerning research and scholarship and librarianship.

\section{Research and Scholarship Included in Professional Practice and/or Normal Workload}

The analysis of collective agreements and policies and the survey results reveal that the inclusion of research and scholarship in professional practice and workload is an ongoing issue and challenge for librarians at many Canadian universities examined in this study. There is significant variation in librarians' rights and ability to pursue research and scholarship due to inconsistent collective agreement language/policies across institutions. Some institutions offer support to librarians, while others perceive research and scholarship as options to be restrained rather than encouraged. Inconsistencies may be due to the history of individual institutions or the trajectory of collective bargaining. As a consequence, tensions may arise between scholarly activity and other professional responsibilities. The responses in table 5 suggest a lack of support from administrators is an issue at some institutions. Also, librarians are not always in agreement about the role of research and scholarship in the profession, which often stems from insufficient research training, ${ }^{55}$ institutional differences, workload issues, and less to do with the actual pursuit of research and scholarship. Given the lack of time and high expectations in workload there is a fear that there will not be enough time to pursue scholarship, which, in turn, will impact their performance, merit, progress through the ranks, and promotion opportunities. ${ }^{56}$ Melissa Goldsmith discusses the less than welcoming attitudes toward the librarian-scholar and the underlying concern by administrators that scholar-librarians will put their scholarship before their library responsibilities. ${ }^{57}$

\section{Definitions of Research and Scholarship}

Inconsistent definitions for research and scholarship are prevalent in librarians' policies and collective agreement language. Ambiguous definitions and opaque language are open to interpretation and also negotiation. The narrowest definition for librarians' research and scholarship is that which restricts it to professional practice or LIS. In 2008 the Canadian Association of Research Libraries (CARL) issued a recommendation that "priorities for CARL research should be established based on the 'burning questions' and priorities for research as identified by CARL directors in the CARL Education Working Group surveys" in evidence-based scholarship. ${ }^{58}$ Research priorities as stipulated by the CARL directors refer to different sectors of librarians' professional practice. ${ }^{59}$ As demonstrated, this trend has crept into collective agreements and policy language, constraining librarians' academic freedom rights to freely engage in disciplinary academic scholarship, despite librarians being protected under academic freedom statements. This suppresses curiosity-driven research and scholarship outside of LIS that may benefit the public good or question the status quo. While it is acknowledged that collective agreement/policy language may also restrict the research of faculty members to their "area of academic expertise," 60 it can be argued that librarians have more than one area of expertise and therefore should not be restricted to LIS research. Given the increase in librarians obtaining more than one graduate degree, this can result in negative tensions. In the most recent $8 R$ s Redux: CARL Human Resources Study, it is reported that "a total of $37 \%$ of librarians have earned at least two graduate degrees (MLIS plus 32\% with a second Master's degree; 5\% with a PhD)." ${ }^{\prime 61}$ In addition, the survey results reveal that collective agreement language does not necessarily provide librarians the freedom to pursue their own research agenda. There is often consider- 
able managerial control by supervisors. Subject discipline research is discouraged at a number of institutions regardless of librarians' rights. There appears to be greater autonomy and protection at institutions where librarians are in the same bargaining unit as faculty. ${ }^{62}$ By limiting librarians' research to professional practice and LIS, the full benefit of librarians pursuing unfettered research is negated. Frederick Isaac writes that "librarians should be open to all serious avenues of research" and if librarians can "raise the level of a discipline's discourse, or can change its direction by submitting their own work, they should be encouraged to do so."63

Even library associations appear to have difficulty in acknowledging how research and scholarship outside library and information science is beneficial for an institution. For example, The Joint Statement on Faculty Status of College and University Librarians issued by the American Library Association (ALA) and the American Association of University Professors (AAUP) clearly supports research and scholarship but within the professional practice of librarianship or library and information science:

They are involved in the research function and conduct research in their own professional interests and in the discharge of their duties. Their scholarly research contributes to the advancement of knowledge valuable to their discipline and institution. ${ }^{64}$

The support for "evidence-based scholarship" within the profession of academic librarianship is a positive movement when it recognizes that this is just one field of inquiry within the wider areas of subject expertise in which academic librarians pursue scholarship. ${ }^{65}$ When collective agreements/policies deny areas of research because they fall outside the framework of what is being defined as "evidence-based scholarship" or "library and information science" for librarians, then the academic freedom of librarians is threatened and deliberately curtailed.

The inclusion of professional development or professional contributions as a form of scholarship is a double-edged sword for the profession. On the one hand, it can be understood as inclusive, widening the options for librarians. On the other hand, it can diminish the singular value of pursuing research and scholarship in the profession. Not differentiating between professional development and scholarship supports inconsistent standards and perspectives within the profession, which leads to a lack of clarity for professionals. ${ }^{66}$ The integration of distinctly different areas, such as scholarship, education, and professional development under one umbrella, creates a constant tension and ambiguity and, ultimately, a lack of support for librarians' scholarship. The collective agreements/policies that strive for parity between faculty and librarians in the area of scholarship and academic freedom do not include professional development as a form of research and scholarship.

\section{Restrictions on Research and Scholarship}

Both the analysis of collective agreements/policies and the survey results reveal that the most common restriction on research and scholarship for librarians is the lack of time. There are considerable differences among institutions regarding time made available and the need for approval. Even librarians for whom research was included as a responsibility indicated that they had difficulty conducting research. As pointed out by Fox, "the requirement for formal scholarship by Canadian research university librarians appears to be a growing trend; and, yet, there are no commonly accepted norms for the appropriate balance between scholarship and other professional responsibilities. ${ }^{167}$ Language in a number of collective agreements/policies is unclear and open to interpretation underpinned by significant managerial oversight and discretion. Many 
collective agreements/policies were negotiated years prior to when the pursuit of research and scholarship by librarians was widely understood, accepted, or even viewed as desirable. Securing provisions to conduct research has been a long and hard-fought struggle at the bargaining table. The biennial CAUT Librarian Salary and Academic Status Survey marks the progress of librarians employed at Canadian universities over the years in securing provisions for research and scholarship. ${ }^{68}$ It is widely accepted that for faculty members the typical expectation is that they will devote 40 percent of their workload to teaching, 40 percent to research, and 20 percent to service. ${ }^{69}$ This similar distribution is highly unlikely for librarians, given the focus on practice and the potential impact on the daily operation of the library. However, it is clear that a negotiated and agreed amount of time to dedicate to research and scholarship within regular workload is needed.

\section{Conclusion}

The analysis of collective agreements and policies, in addition to the results of the 2014 survey, demonstrate that not all librarians employed at Canadian universities have the freedom to conduct research and scholarship and the ability to freely pursue their own research agenda based on their individual expertise or disciplinary interests. While work remains to ensure all academic librarians have the same academic freedom statement, rights, and protection as faculty, this is not where the greatest restrictions on research and scholarship exist for librarians. Our findings reveal that a range of restrictions are imposed within the collective agreements/policies that seek to direct, manage, and censor librarians' research activities. Collective agreements and policies are a product of their institutional history and reflect the efforts of many who have worked to revise, change, and improve conditions over the decades. Not every collective agreement or policy examined is mentioned in this article; and references to collective agreements are essentially devoid of their historical context to allow the focus to remain on specific ideas, language, and terminology that have professional significance for academic librarianship. It is not the intent to focus on a particular institution or collective agreement or to undermine or misrepresent in any way the hard work achieved in negotiating these agreements. Rather, the intent is to demonstrate how the language, the choice of specific terms, words, and phrases can influence, restrict, and subtly redefine the professional autonomy of academic librarians. The findings reveal trends emerging in collective agreements and policies for librarians, which librarians must be aware of. Furthermore, the findings reveal that collective agreement/policy language does not necessarily mean that librarians have the rights and freedoms with respect to research and scholarship to which they are entitled. It is hoped that future research will move beyond the focus on LIS research and explore in depth the benefits, challenges, and impact of disciplinary research for librarians. In addition, not explored in this study and worthy of examination is whether academic librarians have academic freedom with respect to other scholarly activities such as conference presentations, invitations to speak, and applications for research funding.

It is widely understood that, for librarians, academic status should mirror the faculty model and is composed of professional practice, research and scholarship, and service. Meanwhile tenure, academic freedom, peer review, and scholarship are interdependent components that define and reinforce academic status. Scholarship and the creation and dissemination of new knowledge can play an important role in raising the profile of librarians in the university. As Fleming-May and Douglass point out, "because producing original scholarship is one of the most powerful symbols of academic participation," it has been observed that "librarians' commitment to this endeavor sends a powerful message to disciplinary faculty." ${ }^{170}$ Kempcke argues that 
"it is vitally important that librarians measure up to the publishing standards of their campus colleagues - that they participate in the production of scholarly research, which is a critical component of good teaching and camaraderie in the academy."71 Nonetheless, ongoing tensions and differences of opinion remain within and outside the profession regarding the demands and values of research and scholarship. Generally, however, the distance between those who undertake and those who do not undertake scholarship is declining. ${ }^{72}$ But, as some collective agreements/policies reveal, research and scholarship are not always a requirement, no matter how broadly they are defined, which perpetuates disputed differences.

Academic librarians are scholars and researchers in their own right and in a wide range of disciplines that extend beyond LIS. As full members of the academy, they are entitled to the same academic freedom protections as their faculty counterparts. Therefore, it is paramount that academic librarians have the freedom to pursue research and scholarship, as well as unrestricted lines of inquiry in their research and scholarship. For this, the following conditions need to be in place:

- Librarians must be covered by an academic freedom statement.

- Librarians must have the same academic freedom statement as faculty members.

- Research and scholarship must be understood as a component of professional practice and part of the normal or regular workload for librarians.

- An expanded definition of research and scholarship must be used that recognizes subject expertise and creative expression.

To conclude, it is hoped that this study will encourage a collective awareness that transcends institutional boundaries. It is hoped that librarians will be encouraged to scrutinize their own collective agreements and policies with the aim of seeking improvements that recognize their roles and contributions as researchers and scholars and also to encourage administrators, faculty, and leaders in the field of LIS to support them in this endeavour.

\section{Notes}

1. Rachel Fleming-May and Kimberley Douglass, "Framing Librarianship in the Academy: An Analysis Using Bolman and Deal's Model of Organizations," College \& Research Libraries 75, no. 3 (May 2014): 391, doi:10.5860/crl13-432.

2. Richard Atkinson, "Academic Freedom and the Research University," Proceedings of the American Philosophical Society 148, no. 2 (June 2004): 202, available online at http://rca.ucsd.edu/ speeches/Academic\%20Freedom\%20Paper\%20-\%20Web.pdf [accessed 30 August 2017].

3. Ken Kempcke, "The Art of War for Librarians: Academic Culture, Curriculum Reform, and Wisdom from Sun Tzu," portal: Libraries and the Academy 2, no. 4 (Oct. 2002): 534, Project MUSE, doi:10.1353/pla.2002.0081.

4. Fleming-May and Douglass, "Framing Librarianship in the Academy," 394.

5. Shin Freedman, "Faculty Status, Tenure and Professional Identity: A Pilot Study of Academic Librarians in New England," portal: Libraries and the Academy 14, no. 4 (Oct. 2014): 534, Project MUSE, doi:10.1353/pla.2014.0023.

6. Canadian Association of University Teachers, "Librarians in Canada's Universities \& Colleges: State of the Profession 2000-2014," CAUT Education Review (May 2017): 10, available online at https://www.caut.ca/sites/default/files/caut-education-review-2017-05_0.pdf [accessed 30 August 2017].

7. Canadian Association of Research Libraries, Core Competencies for 21st Century CARL Librarians (Oct. 2010), available online at www.carl-abrc.ca/doc/core_comp_profile-e.pdf [accessed 30 August 2017]; Association of College and Research Libraries, Standards for Faculty Status for College and University Librarians (2011), available online at www.ala.org/acrl/standards/standardsfaculty [accessed 30 August 2017]; Association of College and Research Libraries, A Guideline for the Appointment, Promotion and Tenure of Academic Librarians (2010), available online at www.ala.org/acrl/ standards/promotiontenure [accessed 30 August 2017].

8. Canadian Association of University Teachers, Academic Status and Governance for Librar- 


\section{Academic Freedom and Librarians' Research and Scholarship 945}

ians at Canadian Universities and Colleges (2004), available online at https://www.caut.ca/about-us/ caut-policy/lists/caut-policy-statements/policy-statement-on-academic-status-and-governancefor-librarians-at-canadian-universities-and-colleges [accessed 30 August 2017]; Joint Committee on College Library Problems, Association of College and Research Libraries Joint Statement on the Faculty Status of College and University Librarians (Oct. 2012), available online at www.ala.org/acrl/ standards/jointstatementfaculty [accessed 30 August 2017].

9. Catherine Sassen and Diane Wahl, "Fostering Research and Publication in Academic Libraries," College \& Research Libraries 75, no. 4 (July 2014): 466, doi:10.5860/crl.75.4.458; David Fox, "Finding Time for Scholarship: A Survey of Canadian Research University Librarians," portal: Libraries and the Academy 7, no. 4 (Oct. 2007): 453, Project MUSE, doi:10.1353/pla.2007.0041.

10. Canadian Association of University Teachers, “Librarians in Canada's Universities \& Colleges," 10.

11. Melissa Ursula Dawn Goldsmith, "The Librarian-Scholar in 'General Reference Wonderland': A Concurrent Career Academic Librarian's Journey to Keeping Her Scholarly Identity," Codex: The Journal of the Louisiana Chapter of the ACRL 1, no. 1 (2010): 20-48, available online at http:// journal.acrlla.org/index.php/codex/article/view/3 [accessed 30 August 2017]; Marie R. Kennedy and Kristin R. Brancolini, "Academic Librarian Research: A Survey of Attitudes, Involvement, and Perceived Capabilities," College \& Research Libraries 73 no. 5 (Sept. 2012): 431-48, doi:10.5860/ crl-276.

12. Selinda Adelle Berg, Heidi L.M. Jacobs, and Dayna Cornwall, "Academic Librarians and Research: A Study of Canadian Library Administrator Perspectives," College \& Research Libraries 74, no. 6 (Nov. 2013): 560-72, doi:10.5860/crl12-366.

13. S. Craig Finlay, Chaoqun Ni, Andrew Tsou, and Cassidy R. Sugimoto, "Publish or Practice? An Examination of Librarians' Contributions to Research," portal: Libraries and the Academy 13, no. 4 (Oct. 2013): 403-21, Project MUSE, doi:10.1353/pla.2013.0038; Miggie Pickton, "Supporting Research by Becoming a Researcher: How Librarians Can Use Their Own Research Experience to Benefit Library Users," ALISS Quarterly 9 no. 1 (2013): 10-15, available online at http://nectar. northampton.ac.uk/5614/3/Pickton20135614.pdf [accessed 30 August 2017]; Gay Helen Perkins and Amy J.W. Slowik, "The Value of Research in Academic Libraries," College \& Research Libraries 75, no. 4 (Mar. 2013): 143-58, doi:10.5860/crl-308.

14. Sassen and Wahl, "Fostering Research and Publication in Academic Libraries," 458-91.

15. Denise Koufogiannakis and Ellen Crumley, "Research in Librarianship: Issues to Consider," Library Hi Tech 24, no. 3 (2006): 324-40, doi:10.1108/07378830610692109.

16. Ronald R. Powell, Lynda Baker, and Joseph Mika, "Library and Information Science Practitioners and Research," Library \& Information Science Research 24, no. 1 (2002): 49-72, doi:10.1016/ S0740-8188(01)00104-9; Association of College and Research Libraries, Standards for Proficiencies for Instruction Librarians and Coordinators: A Practical Guide (2008): 10-11, available online at www.ala. org/acrl/sites/ala.org.acrl/files/content/standards/profstandards.pdf [accessed 30 August 2017].

17. José Montelongo, Lynne Gamble, Navjit Brar, and Anita C. Hernandez, "Being a Librarian Isn't Enough: The Importance of a Nonlibrary Research Agenda for the Academic Librarian: A Case Study," College \& Undergraduate Libraries 17, no. 1 (2010): 2-10, doi:10.1080/10691310903584742.

18. Susan E. Thomas and Anne E. Leonard, "Interdisciplinary Librarians: Self-Reported NonLIS Scholarship and Creative Work," Library Management, vol. 35, nos. 8/9 (2014): 547, doi:10.1108/ LM-02-2014-0030.

19. Kathleen DeLong, Marianne Sorensen, and Vicki Williamson, 8Rs Redux: CARL Libraries Human Resources Study (May 2015), available online at www.carl-abrc.ca/doc/8Rs\%20REDUX\%20 Final\%20Report\%20Oct\%202015.pdf [accessed 30 August 2017]; Thea Lindquist and Todd Gillman, "Academic/Research Librarians with Subject Doctorates: Experiences and Perceptions, 1965-2006," portal: Libraries and the Academy 10, no. 4 (Oct. 2010): 399-412, Project MUSE, doi:10.1353/pla.2010.0007.

20. Finlay, Ni, Tsou, and Sugimoto, "Publish or Practice?"; Goldsmith, "The Librarian-Scholar in 'General Reference Wonderland'"; Perkins and Slowik, "The Value of Research in Academic Libraries"; Kennedy and Brancolini, "Academic Librarian Research"; Fox, "Finding Time for Scholarship."

21. Sassen and Wahl, "Fostering Research and Publication in Academic Libraries," 459.

22. Jesse D. Mann, "Intellectual Freedom, Academic Freedom, and the Academic Librarian," AAUP Journal of Academic Freedom 8 (2017): 1, available online at https://www.aaup.org/JAF8/ intellectual-freedom-academic-freedom-and-academic-librarian\#.Wihiy3m1upo [accessed 6 December 2017].

23. Richard A. Danner and Barbara Bintliff, "Academic Freedom Issues for Academic Librarians," Legal Reference Services Quarterly 25 no.4 (2006): 19, available online at http://scholarship. law.duke.edu/cgi/viewcontent.cgi?article=2275\&context=faculty_scholarship [accessed 30 August 2017]. 
24. Mary Kandiuk and Harriet Sonne de Torrens, "Librarians in a Litigious Age and the Attack on Academic Freedom," in Current Issues in Libraries, Information Science and Related Fields, Advances in Librarianship 39, eds. Anne Woodsworth and W. David Penniman (Bingley, U.K.: Emerald Publishing, Ltd. 2015): 12.

25. Shannon Oltmann, "Intellectual Freedom in Academic Libraries: Surveying Deans about Its Significance," College \& Research Libraries 78, no. 6 (Sept. 2017): 3, doi:10.5860/crl.78.6.741.

26. David Bromwich, "Academic Freedom and Its Opponents," Raritan 31, no. 3 (2012): 19-33.

27. Fox, "Finding Time for Scholarship," 453.

28. David Fox, "The Scholarship of Canadian Research University Librarians," Partnership: The Canadian Journal of Library and Information Practice and Research 2, no. 2 (2007): 7, available online at https://journal.lib.uoguelph.ca/index.php/perj/article/view/305/562\#.WbbKp8a1upo [accessed 30 August 2017].

29. Marni R. Harrington and Natasha Gerolami, "Highs and Lows: An Examination of Academic Librarians' Collective Agreements," in In Solidarity: Academic Librarian Labour Activism and Union Participation in Canada, eds. Jennifer Dekker and Mary Kandiuk (Sacramento, Calif.: Library Juice Press, 2014), 151-69.

30. Harrington and Gerolami, "Highs and Lows," 160, 164-65.

31. Atkinson, "Academic Freedom and the Research University."

32. Alison Prentice, "Bluestockings, Feminists, or Women Workers? A Preliminary Look at Women's Early Employment at the University of Toronto," Journal of the Canadian Historical Association / Revue de la Société historique du Canada 2, no. 1 (1991): 231-62; Roma Harris, "Keeping Silent About Women" in Librarianship: The Erosion of a Woman's Profession (Norwood, N.J.: Ablex Publishing Corporation, 1992), 12-14; Bertha Bassam, The Faculty of Library Science, University of Toronto and Its Predecessors 1911-1972 (Toronto, Ontario: University of Toronto Press, 1978); Christine L. Williams, Still a Man's World: Men Who Do Women's Work (University of California Press, 1995), 23; Harriet Sonne de Torrens, "Academic Librarianship: The Quest for Rights and Recognition at the University of Toronto," in In Solidarity: Academic Librarian Labour Activism and Union Participation in Canada, eds. Jennifer Dekker and Mary Kandiuk (Sacramento, Calif.: Library Juice Press, 2014), 85-87.

33. Nancy Kiefer, "The Impact of the Second World War on Female Students at the University of Toronto 1939-1949" (M.A. thesis, University of Toronto, 1984), 126; Jane Simon, “The Construction of Femininity in Discourses of the Woman Librarian: 1890s to 1940s," Australian Library Journal 43, no. 4 (1994): 257-71.

34. Kandiuk and Sonne de Torrens, "Librarians in a Litigious Age," 9-11.

35. Joanna Bornat and Hannah Diamond, "Women's History and Oral History: Developments and Debates," Women's History Review 16, no. 1 (2007(): 19-39; Margaret Redfern, "Feminism and Education for Library and Information Work," Library Management 5, no. 4 (1984): 23-29; Sonne de Torrens, "Academic Librarianship," 94-95.

36. Jean Weihs, "The Emergence of Library Technician Programs in Canada: A Brief History," Feliciter 54, no. 2 (2008): 70-73.

37. Catherine Coker, Wyoma vanDuinkerken, and Stephen Bales, "Seeking Full Citizenship: A Defense of Tenure Faculty Status for Librarians," College \& Research Libraries 71, no. 5 (Sept. 2010): 408-10, doi:10.5860/crl-54r1. 83.

38. Bassam, The Faculty of Library Science, University of Toronto and Its Predecessors 1911-1972,

39. The Supply of Librarians: A Report to the Presidents of the Provincially Assisted Universities of Ontario from the Presidents' Research Committee (Feb. 5, 1964).

40. Sonne de Torrens, "Academic Librarianship," 86-87.

41. Montelongo, Gamble, Brar, and Hernandez, "Being a Librarian Isn't Enough," 2-10.

42. Government of Canada, "Constitution Act, 1982, Part 1, Fundamental Freedoms, 2.b," (1982), available online at http://laws-lois.justice.gc.ca/eng/Const/page-15.html [accessed 30 August 2017].

43. United Nations, Universal Declaration of Human Rights (1949), available online at www. un.org/en/universal-declaration-human-rights/ [accessed 30 August 2017].

44. Kandiuk and Sonne de Torrens, "Librarians in a Litigious Age," 8-9.

45. Arthur McAnally, "Status of the University Librarian," in ACRL Committee on Academic Status (comp.), Faculty Status for Academic Librarians: A History and Policy Statement (Chicago, Ill.: American Library Association, 1975): 1-30; Richard A. Danner and Barbara Bintliff, "Academic Freedom Issues for Academic Librarians," Legal Reference Services Quarterly 25, no. 4 (2006): 13-35, available online at http://scholarship.law.duke.edu/cgi/viewcontent.cgi?article=2275\&context=fa culty_scholarship [accessed 30 August 2017]; Wendy Highby, "The Ethics of Academic College Development in a Politically Contentious Era," Library Collections, Acquisitions \& Technical Services 28, no. 4 (2004): 465-72; Richard Rubin, Foundations of Library and Information Science (New York, 


\section{Academic Freedom and Librarians' Research and Scholarship 947}

N.Y.: Neal-Schuman, 2000).

46. Association of College and Research Libraries, Association of College and Research Libraries Joint Statement on Faculty Status of College and University Librarians (Oct. 2012), available online at www.ala.org/acrl/standards/jointstatementfaculty [accessed 30 August 2017].

47. Mann, "Intellectual Freedom, Academic Freedom, and the Academic Librarian," 3.

48. Kandiuk and Sonne de Torrens, "Librarians in a Litigious Age," 3-45.

49. Canadian Association of University Teachers, "Table C / Tableau C: Academic Status of Librarians, Statut universitaire de bibliothécaires" (2014).

50. Alberta (7 out of 8), British Columbia (9 out of 11), Manitoba (3 out of 6), New Brunswick (2 out of 4$)$, Nova Scotia (7 out of 9), Newfoundland (1 out of 1), Ontario (24 out of 31), Prince Edward Island (1 out of 1), Quebec (3 out of 19), and Saskatchewan (2 out of 6).

51. Government of Canada, Negotech, available online at http://negotech.labour.gc.ca/cgi-bin/ recherche-search/nego/index.aspx?GoCTemplateCulture=en-CA [accessed 30 August 2017].

52. For the results of the study relating to the second part of the survey, see Kandiuk and Sonne de Torrens, "Librarians in a Litigious Age."

53. Fox, "Finding Time for Scholarship," 452.

54. Association of College and Research Libraries, Association of College and Research Libraries Standards for Faculty Status for Academic Librarians (2011), available online at www.ala.org/acrl/ standards/standardsfaculty [accessed 30 August 2017].

55. Kennedy, "Academic Librarian Research," 432; Sassen and Wahl, "Fostering Research and Publication in Academic Libraries," 458.

56. Fox, "Finding Time for Scholarship," 452.

57. Goldsmith, "The Librarian-Scholar in 'General Reference Wonderland'," 20.

58. Vicki Williamson et al., "Library Education Working Group: Final Report to the CARL Board of Directors" (Spring 2008), 2.

59. Canadian Association of Research Libraries, "Librarians as Researchers and Writers: Priorities for Canada's Research Libraries" (2010), available online at http://www.carl-abrc.ca/doc/ writers-1.pdf [accessed 6 December 2017].

60. Faculty Collective Agreement between The University of Western Ontario and The University of Western Ontario Faculty Association July 1 2014-June 30, 2018, 8, available online at www.uwo.ca/ facultyrelations/pdf/collective_agreements/faculty.pdf [accessed 6 December 2017].

61. DeLong, Sorenson, and Williamson, 8 Rs Redux, 100.

62. Mary Kandiuk, "Academic Librarians at the Table-Bargaining for Parity," in In Solidarity: Academic Librarian Labour Activism and Union Participation in Canada, eds. Jennifer Dekker and Mary Kandiuk (Sacramento, Calif.: Library Juice Press, 2014), 202.

63. Frederick Isaac, "Librarian, Scholar or Author? The Librarian's New Dilemma," Journal of Academic Librarianship 9, no. 4 (Sept. 1983): 216-20.

64. Joint Committee on College Library Problems, Association of College and Research Libraries Joint Statement, paragraph 3.

65. Fox, "The Scholarship of Canadian Research University Librarians," 20.

66. Carol A. Parker, "The Need for Faculty Status and Uniform Tenure Requirements of Law Librarians," Law Library Journal 103 no. 1 (2011): 7-38, available online at http://works.bepress. com/aallcallforpapers/67/ [accessed 30 August 2017].

67. Fox, "Finding Time for Scholarship," 452.

68. Canadian Association of University Teachers, "Table D / Tableau D: Academic Status of Librarians, Statut universitaire de bibliothécaires" (2014).

69. Linda Jonker and Martin Hicks, Teaching Loads and Research Outputs of Ontario University Faculty Members: Implications for Productivity and Differentiation (Higher Education Quality Council of Ontario, March 11, 2014): 7, available online at www.heqco.ca/SiteCollectionDocuments/ FINAL\%20Teaching\%20Loads\%20and\%20Research\%20Outputs\%20ENG.pdf [accessed 6 December 2017].

70. Fleming-May and Douglass, "Framing Librarianship in the Academy," 402.

71. Kempcke, "The Art of War for Librarians," 534.

72. Selinda Adelle Berg, Kristin Hoffmann, and Diane Dawson, "Integrating Research into LIS Field Experiences in Academic Libraries," Journal of Academic Librarianship 35, no. 6 (2009): $591-98$. 